\title{
Response of Six Potato Cultivars to Amount of Applied Water and Verticillium dahliae
}

\author{
M. Arbogast, M. L. Powelson, M. R. Cappaert, and L. S. Watrud
}

First and third authors: Orbiting Astronomical Observatory (OAO) c/o United States Environmental Protection Agency (USEPA), 200 SW Western, Corvallis, OR 97331-2902; second author: Department of Botany and Plant Pathology, Oregon State University, Corvallis 973312902; and fourth author: USEPA, 200 SW 35th Street, Corvallis, OR 97333. Accepted for publication 27 May 1999.

\begin{abstract}
Arbogast, M., Powelson, M. L., Cappaert, M. R., and Watrud, L. S. 1999. Response of six potato cultivars to amount of applied water and Verticillium dahliae. Phytopathology 89:782-788.

Six potato cultivars were grown with or without the addition of Verticillium dahliae inoculum and were watered at 50,75 , or $100 \%$ estimated consumptive use. The applied water $\times$ cultivar interaction was significant ( $P=0.009$ and $P=0.001$ for 1996 and 1997, respectively) for the relative area under the senescence progress curve (RAUSPC). With a decrease in water, there was an increase in RAUSPC. A significant interaction of

lium wilt. Population size of $V$. dahliae in stem apices was significantly lower in 'Katahdin' in both 1996 and $1997(P=0.0001)$ and in 'Ranger Russet' in $1997(P=0.0001)$ than in the other cultivars. 'Russet Burbank' and 'Shepody' had large apical stem populations of $V$. dahliae and higher RAUSPC values associated with both $V$. dahliae inoculum and decreased amount of applied water. Marketable tuber yield was unaffected by $V$. dahliae in both years. Cultivar resistance to Verticillium wilt was related to cultivar tolerance to moisture deficit stress. Results suggest that moisture deficit stress response has the potential to be a useful tool in protocols for screening potato for Verticillium resistance.
\end{abstract} inoculum density $\times$ cultivar also was found, based on RAUSPC $(P=$ 0.0194 and $P=0.0033$ for 1996 and 1997, respectively). In $V$. dahliaeinfested plots, 'Katahdin' and 'Ranger Russet' were resistant to Verticil-
Additional keywords: drought tolerance, potato early dying, Solanum tuberosum.
Verticillium wilt, caused by the soilborne fungus Verticillium dahliae Kleb., is a disease limiting potato production in both irrigated and nonirrigated production areas of the world. The disease results in premature senescence of the foliage; the earlier the onset of senescence, the greater the yield reduction. Yield losses of up to $50 \%$ have been reported $(19,34,37)$. This disease is controlled by soil fumigation, long-term crop rotations, soil solarization $(14,19)$, the plow down of green manures (16), and modification of cultural practices such as fertility (15) and irrigation $(6,15)$. A few resistant cultivars with market acceptance have been released $(9-11,14)$.

Two environmental factors that influence the severity of Verticillium wilt are temperature and soil moisture $(35,36)$. When air temperatures are in the optimum range for colonization of the vascular tissue by $V$. dahliae, disease can be severe (22). The relationship between soil moisture status and disease severity in agronomic and horticultural species, however, has been variable. For example, severity of wilt symptoms has been associated with amount of applied water, frequency of irrigation, and drought episodes. Cappaert et al. (5) working with potato and El-Zik (20) with cotton showed that, with an increase in applied water, disease severity was increased. With the desert-native, rubber-producing plant guayule, disease was more severe under frequent versus less frequent irrigations, even though amount of applied water was the same at each irrigation event (40). In contrast, the severity of Verticillium wilt in maple was higher under constant soil moisture deficit stress than under optimum soil moisture conditions (7). Disease ratings were higher (32) when mint was grown in soil at $70 \%$ compared with $85 \%$ field capacity.

Corresponding author: M. Arbogast; E-mail address: arbogast@ mail.cor.epa.gov

Publication no. P-1999-0712-02R

This article is in the public domain and not copyrightable. It may be freely reprinted with customary crediting of the source. The American Phytopathological Society, 1999
Early dying (Verticillium wilt) in potato 'Russet Burbank' can be suppressed if water is reduced prior to tuber initiation (6). When water was applied at $75 \%$ estimated consumptive use (ECU) prior to tuber initiation, a level that induced mild moisture deficit stress, the disease was significantly less severe compared with $150 \%$ ECU, and yields were maintained (6). Studies on the effect of a range in soil moisture levels on Verticillium wilt in other potato cultivars, however, are lacking. Based on the response of 'Russet Burbank' to mild moisture deficit stress, our hypothesis is that cultivars that are tolerant to season-long mild moisture deficit stress will be resistant to Verticillium wilt. The objectives of our research were twofold: (i) to compare potato cultivars for reaction to moisture deficit stress and Verticillium wilt, and (ii) to determine if a cultivar's response to moisture deficit stress is indicative of its response to Verticillium wilt.

\section{MATERIALS AND METHODS}

Field plots. Field plots were established at the Central Oregon Agricultural Research Center in Jefferson County (941-m elevation; 90- to 100-day growing season; Madras, fine loamy, mixed, superactive, and mesic Aridic Argixerolls) on 10 May 1996 and 14 May 1997. Treatments were six potato (Solanum tuberosum L.) cultivars, three amounts of applied water, and two levels of $V$. dahliae inoculum. The experimental design was a split-plot randomized block with amount of applied water as the main plot and cultivar $\times V$. dahliae inoculum as subplots. Each factorial set of treatments was replicated six times.

Inoculum production. Six single-spore isolates of $V$. dahliae from symptomatic potato plants collected from Umatilla and Jefferson Counties in 1995 were grown on potato dextrose agar. The plates were flooded with sterile water, and 200- $\mu$ l aliquots of the conidial suspension were pipetted into tubes with $9 \mathrm{ml}$ of CzapexDox broth. The broth was shaken in the dark at $22^{\circ} \mathrm{C}$ at $60 \mathrm{rpm}$ for 48 to $72 \mathrm{~h}$. Fully hydrated rye grain was autoclaved for $40 \mathrm{~min}$, 
and approximately 1 liter was placed in mushroom spawn bags (Northwest Mycological Consultants, Corvallis, OR). Bags were closed, autoclaved for $80 \mathrm{~min}$, and cooled to $22^{\circ} \mathrm{C}$ in a laminar flow hood. One 9-ml tube of the $V$. dahliae spore suspension was added to each bag, with final concentrations determined after growth on rye grain. The bags were closed with plastic zip ties and stored in the dark at $22^{\circ} \mathrm{C}$. The rye grain was shaken every 2 days until most of the grain was covered with microsclerotia of $V$. dahliae. The colonized rye grain was spread on greenhouse benches, airdried, and then ground in a Jay Bee Hammermill (Jay Bee, Utica, $\mathrm{NY}$ ). Inoculum density of $V$. dahliae was determined by diluting the ground rye in sterile greenhouse soil and plating the mixture onto Sorensen's modified NP-10 medium (42) with an Andersen air sampler (Andersen Instruments, Smyrna, GA) (4). Appropriate amounts of the colonized rye grain were added to sterile greenhouse soil so that the resulting inoculum density in field plots would be approximately 50 or $100 \mathrm{CFU/g}$ of soil in 1996 and 1997, respectively.

Seed stock. Seed tubers were purchased from certified seed potato growers in the United States. The cultivars Katahdin, Ranger Russet, Red La Soda, Russet Burbank, Shepody, and Viking represented a range in maturity, tuber quality, resistance to Verticillium wilt, and drought tolerance (Table 1).

Plot establishment. Seed tubers were cut into seed pieces weighing 43 to $71 \mathrm{~g}$. Seed pieces were planted in plots of three 6.0-m-long rows. Row width was $86 \mathrm{~cm}$ and seed pieces were spaced $34 \mathrm{~cm}$ apart within the rows. To avoid flooding, border rows between plots were planted to 'Russet Burbank' at plant densities similar to the experimental plot densities. At planting, approximately 50-g (1996) or 100-g (1997) aliquots of $V$. dahliae inoculum were banded alongside the seed pieces of the center row of the Verticillium-infested plots using the fertilizer belt of the potato planter. Inoculum density was estimated by assuming that mixing with the soil would be limited to the volume of soil contained in strips of $6.0 \mathrm{~m}$ long $\times$ $0.3 \mathrm{~m}$ wide $\times 0.15 \mathrm{~m}$ deep.

Irrigation treatments were established with a line source irrigation system, so that a moisture gradient was created perpendicular to the irrigation line. Plots were parallel to the irrigation line, and the center row of each plot was positioned at 2.3, 5.9, or $9.6 \mathrm{~m}$ from the line source. Amount of water applied at each distance was designed to supply 100,75 , or $50 \%$ ECU. Irrigation was scheduled using crop water use calculations based on weather data collected on site and adjusted when visual soil moisture observations indicated excessive soil dryness or wetness. Percent volumetric soil moisture to a depth of $15 \mathrm{~cm}$ was monitored weekly with a timedomain reflectometer (Soil Moisture Equipment Corp., Santa Barbara, CA), and amount of applied water was measured in catch cans after each irrigation and precipitation event.

Response variables. Data were collected on the center row of each plot. When plants began showing foliar symptoms of chlorosis and necrosis, weekly assessments of percent foliar senescence

TABLE 1. Maturity class and reaction to drought and Verticillium wilt in six potato cultivars

\begin{tabular}{|c|c|c|c|}
\hline Cultivar & $\begin{array}{l}\text { Maturity } \\
\text { class }^{\mathrm{v}}\end{array}$ & $\begin{array}{l}\text { Drought } \\
\text { reaction } \\
\mathrm{w}, \mathrm{x}\end{array}$ & $\begin{array}{l}\text { Verticillium wilt } \\
\text { reaction }^{\mathrm{x}}\end{array}$ \\
\hline Katal & Late & Modera & Resistant \\
\hline usset & dium late ${ }^{y}$ & $\mathrm{z}$ & Resistant \\
\hline & Early & $\mathrm{S}$ & \\
\hline Russet Burl & Late & Isitive & Mode \\
\hline & Medi & $\therefore$ & Susce \\
\hline Viking & Medium & Moderately tolerant & Susceptible \\
\hline \multicolumn{4}{|c|}{$\begin{array}{l}\mathrm{v} \text { Late maturity }=180 \text { days, medium maturity }=120 \text { days, and early maturing }= \\
100 \text { days }(30) \text {. }\end{array}$} \\
\hline \multicolumn{4}{|c|}{$\begin{array}{l}\text { w Drought-tolerant cultivars resist wilting as soil dries; drought-sensitive cul- } \\
\text { tivars readily wilt as soil dries. }\end{array}$} \\
\hline \multicolumn{4}{|c|}{$\begin{array}{l}\text { The terms tolerant, sensitive, resistant, and susceptible follow the definitions } \\
\text { of Mosley and Chase }(30) \text {. }\end{array}$} \\
\hline \multicolumn{4}{|c|}{ y S. James, personal communication. } \\
\hline
\end{tabular}

per plot were made on a scale of 0 to $100 \%$. When all cultivars had reached growth stage $\mathrm{V}$ (tuber maturation), one stem per plot in 1996 and three stems per plot in 1997 were harvested for aerial biomass determination. Samples were dried in ovens at approximately $100^{\circ} \mathrm{C}$ and then weighed. In addition, the top $10 \mathrm{~cm}$ of 3 (1996) and 10 (1997) plants were randomly collected from each plot at growth stage V. Leaves were removed, and the stem pieces were dried at $22^{\circ} \mathrm{C}$ for 3 months and ground in a Wiley mill (mesh \#20; Arthur H. Thomas Co., Philadelphia, PA). The ground stems were plated with an Andersen air sampler (4) onto Sorensen's modified NP-10 medium (42) at $0.04 \mathrm{~g}$ per plate. Plates were incubated in the dark at $22^{\circ} \mathrm{C}$ for 7 to 14 days. The agar surface was rinsed under tap water, and colonies of $V$. dahliae were counted with a stereomicroscope.

The center row of each plot was harvested by machine. Tubers were weighed and graded into yield components of U.S. No. 1s ( $<113 \mathrm{~g}, 113$ to $170 \mathrm{~g}, 171$ to $340 \mathrm{~g}$, and $>340 \mathrm{~g}$ ), No. $2 \mathrm{~s}$, and culls. Marketable tuber weight was calculated as the mean total weight per treatment minus the No. $2 \mathrm{~s}$ and culls.

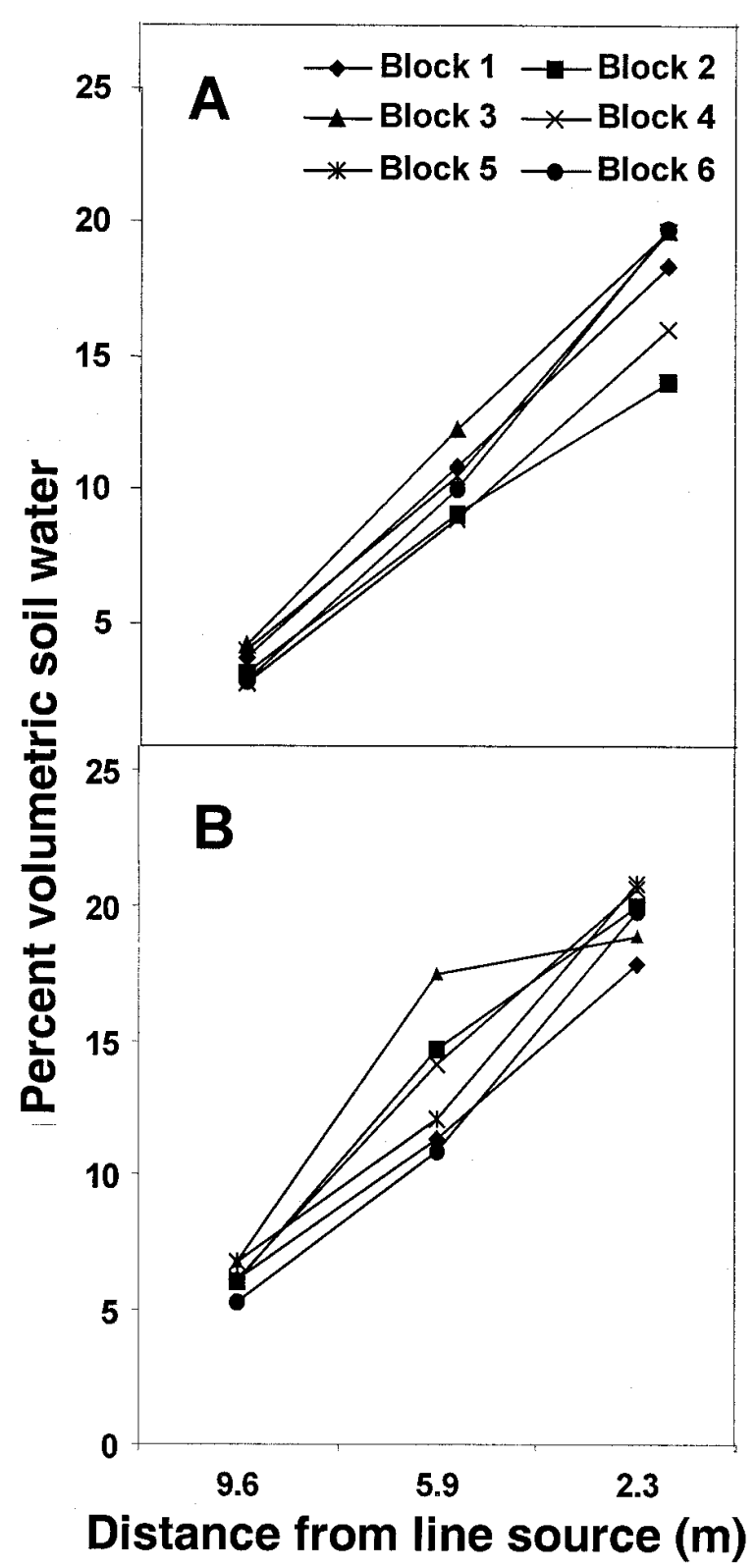

Fig. 1. Percent volumetric soil water measured at each of three treatment distances from an irrigation line source for six replicate blocks in A, 1996 and B, 1997. Percent volumetric soil water was measured to a depth of $15 \mathrm{~cm}$ with a time-domain reflectometer. 
Data analysis. Degree-days after planting (DDAP, base $=12.8^{\circ} \mathrm{C}$ ) was calculated by the methods of Baskerville and Emin (1). Foliar senescence progress curves were generated based on mean percent senescence per treatment. Area under the senescence progress curve was calculated (41) and the value divided by the number of degreedays over the senescence period in order to generate the relative area under the senescence progress curve (RAUSPC). This calculation adjusted for differences in maturity class. Values for aerial biomass and apical stem populations varied by 10 -fold. Therefore, these data were natural logarithm-transformed before analysis. Biomass, RAUSPC, apical populations, and graded tuber yield treatment means were analyzed by the general linear models procedure by SAS, version 6.12 (SAS Institute, Cary, NC). To account for nonrandom assignment of irrigation treatments, the error term designated for the irrigation effect was block $\times$ irrigation. The HuynhFeldt tests of sphericity were used to test the hypothesis that the

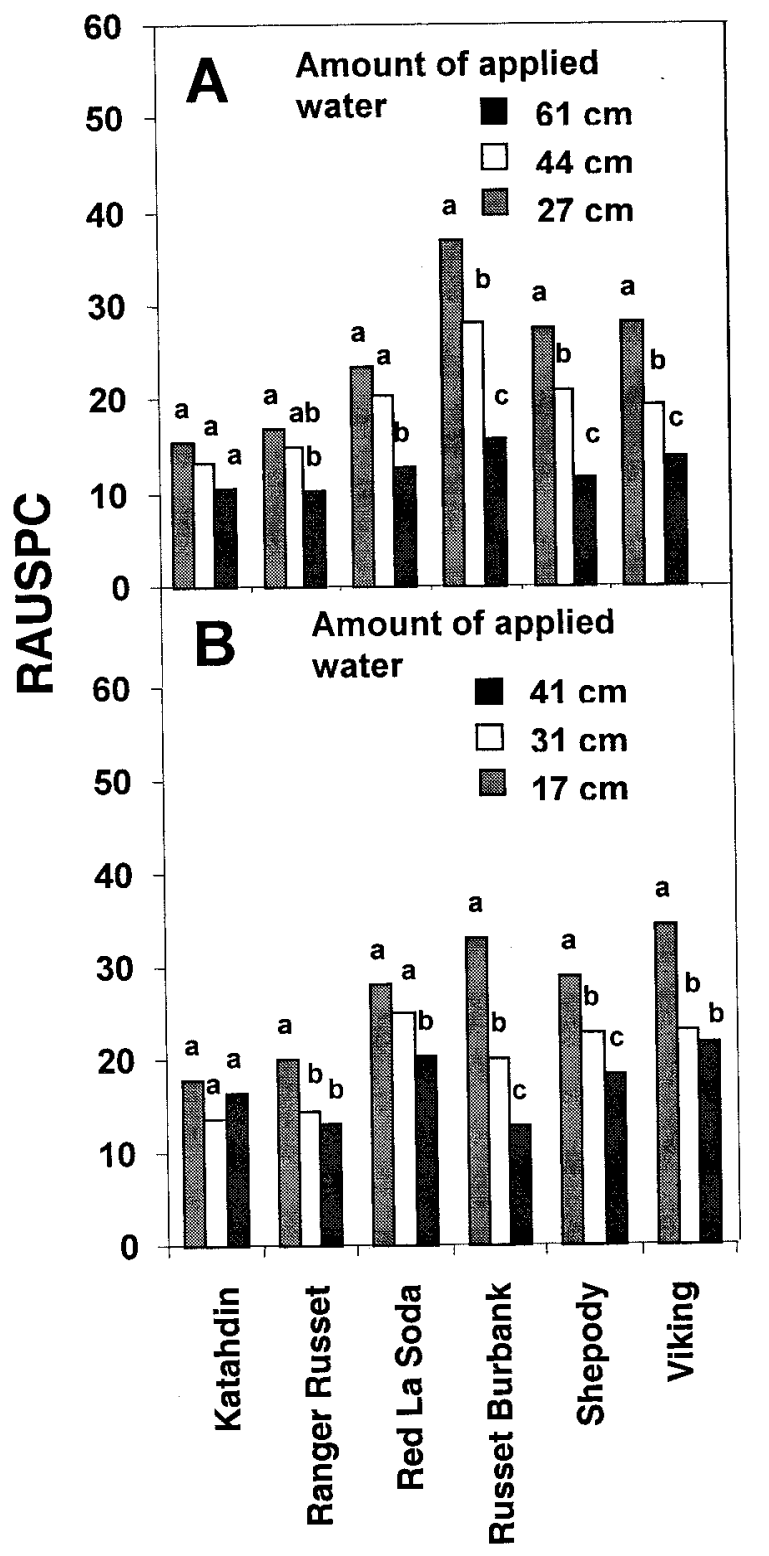

Cultivars

Fig. 2. Amount of applied water $\times$ cultivar interactions on the relative area under the senescence progress curve (RAUSPC) of potato in A, 1996 and $\mathbf{B}$, 1997. Within cultivar, bars with the same letter did not differ significantly according to Fisher's protected least significant difference test $(P \leq 0.05)$. Amount of applied water $\times$ cultivar interaction was $P=0.0090$ in 1996 and $P=$ 0.0194 in 1997. irrigation treatments were not correlated and had equal variance (SAS Institute). If the error term of the irrigation treatment main effect was greater than the error term of the block $\times$ irrigation treatment, a simple model was applied and irrigation main effects were allowed. Treatment means were separated by Fisher's protected least significant difference test.

\section{RESULTS}

Irrigation treatments. Irrigation treatments were initiated 143 and 171 DDAP in 1996 and 1997, respectively. Total amount of applied water for the season (irrigation plus precipitation) at 2.3, 5.9, and $9.6 \mathrm{~m}$ from the irrigation line was 61,44 , and $27 \mathrm{~cm}$ and 41, 31,

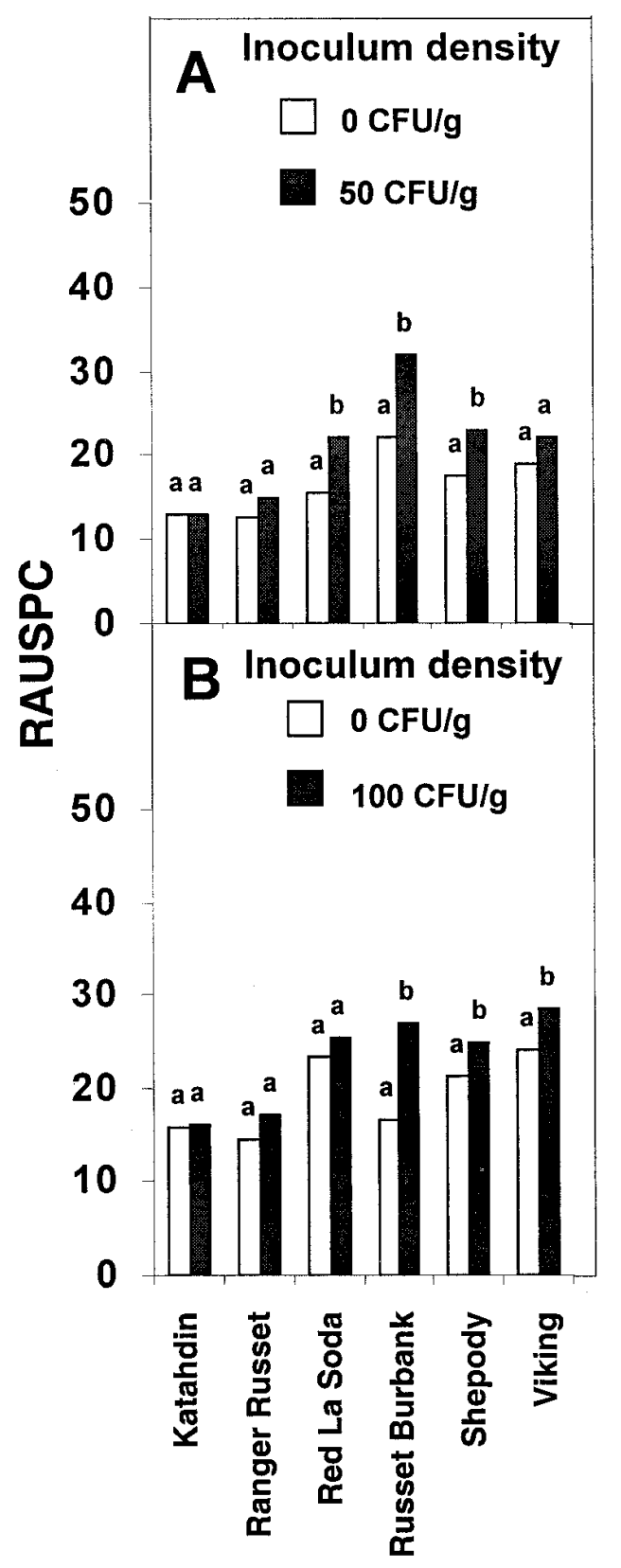

\section{Cultivars}

Fig. 3. Inoculum density of Verticillium dahliae $\times$ cultivar interactions on the relative area under the senescence progress curve (RAUSPC) of potato in $\mathbf{A}$, 1996 and B, 1997. Within cultivar, bars with the same letter did not differ significantly according to Fisher's protected least significant difference test $(P \leq 0.05)$. Inoculum density of Verticillium dahliae $\times$ cultivar interactions was $P=0.0090$ in 1996 and $P=0.0194$ in 1997. 
and $17 \mathrm{~cm}$ in 1996 and 1997, respectively. Amount of applied water per irrigation event averaged $2.9,1.9$, and $1.2 \mathrm{~cm}$ and 1.9, 1.4, and $0.7 \mathrm{~cm}$ for each distance in 1996 and 1997, respectively. For each irrigation event, average percent volumetric soil water content at $15 \mathrm{~cm}$ deep within $24 \mathrm{~h}$ of irrigation at 2.3, 5.9, and $9.6 \mathrm{~m}$ was 18,11 , and $4 \%$ and 18, 12, and $6 \%$ in 1996 and 1997, respectively (Fig. 1). Plots furthest from the irrigation line averaged $<10 \%$ volumetric soil water in both seasons. Most crop plants have osmotic potentials in the range of -1.5 to $-2.0 \mathrm{MPa}$, and water content at $-1.5 \mathrm{MPa}$ is near the point at which soil moisture usually becomes severely limiting (25). At the Madras site, $14.7 \%$ volumetric soil water at $30 \mathrm{~cm}$ corresponds to $-1.5 \mathrm{MPa}$; therefore, mild moisture deficit stress was achieved in the plots furthest from the line source. Plants in these plots were visibly stunted compared with those receiving more water.

Foliar senescence. The interaction between amount of applied water and cultivar for the RAUSPC response variable was significant in both $1996(P=0.0009)$ and $1997(P=0.0194)$ (Fig. 2). In 1996, a decrease in amount of applied water had no effect on foliar senescence in 'Katahdin', but resulted in an overall increase in RAUSPC in the other five cultivars. Increases in RAUSPC ranged from 40 to $80 \%$ when water was reduced from 61 to $44 \mathrm{~cm}$ and ranged from 65 to $135 \%$ when water was reduced from 61 to $27 \mathrm{~cm}$. In 1997, a 24\% reduction in amount of applied water had no effect on RAUSPC for 'Katahdin', 'Viking', and 'Ranger Russet', but had a significant effect on the other cultivars. The increase in RAUSPC ranged from 23 to $55 \%$ when water was reduced from 41 to $31 \mathrm{~cm}$. When applied water was decreased from 41 to $17 \mathrm{~cm}$, RAUSPC was increased by 38 to $153 \%$ in all cultivars but 'Katahdin'.

Foliar senescence was significantly affected by an interaction between cultivar and inoculum density of $V$. dahliae $(P=0.0194$ and $P=0.0033$ in 1996 and 1997, respectively) (Fig. 3). 'Katahdin' and 'Ranger Russet' were resistant and 'Russet Burbank' and 'Shepody' were susceptible to Verticillium wilt as measured by RAUSPC. RAUSPC values of 'Russet Burbank' increased 44 (1996, $P=$ $0.0001)$ and $61 \%(1997, P=0.0001)$ and 'Shepody' RAUSPC values increased $31(1996, P=0.0001)$ and 19\% $(1997, P=0.0244)$ when grown in infested compared with noninfested plots. Responses

TABLE 2. Main effect of amount of applied water on aerial biomass of potato across cultivar and Verticillium dahliae inoculum density in 1996 and 1997

\begin{tabular}{lll}
\hline & \multicolumn{2}{c}{ Aerial biomass $^{\mathrm{y}}$} \\
\cline { 2 - 3 } Irrigation treatment $^{\mathrm{x}}$ & 1996 & 1997 \\
\hline Low & $2.68 \mathrm{a}^{\mathrm{z}}$ & $3.04 \mathrm{a}$ \\
Medium & $3.21 \mathrm{~b}$ & $3.51 \mathrm{~b}$ \\
High & $3.64 \mathrm{c}$ & $3.91 \mathrm{c}$ \\
\hline
\end{tabular}

${ }^{\mathrm{x}}$ Water was applied by a line source irrigation system. A total of 27,44 , or $61 \mathrm{~cm}$ and 17, 31, or $41 \mathrm{~cm}$ of water was applied in 1996 and 1997, respectively. ${ }^{\mathrm{y}}$ Values presented are $\ln ($ aerial biomass [g]) at potato growth stage $\mathrm{V}$.

${ }^{\mathrm{z}}$ Within year, values with the same letter did not differ significantly according to Fisher's protected least significant difference test $(P \leq 0.05)$.

TABLE 3. Population size of Verticillium dahliae in stem apices of six potato cultivars grown in Verticillium-infested soil with three amounts of applied water in 1996 and 1997

\begin{tabular}{lll}
\hline & \multicolumn{2}{c}{ Population size $^{\mathrm{y}}$} \\
\cline { 2 - 3 } Cultivar & 1996 & 1997 \\
\hline Katahdin & $2.5 \mathrm{a}^{\mathrm{z}}$ & $3.8 \mathrm{a}$ \\
Ranger Russet & $5.1 \mathrm{~b}$ & $3.8 \mathrm{a}$ \\
Red La Soda & $5.5 \mathrm{bc}$ & $6.4 \mathrm{c}$ \\
Russet Burbank & $5.7 \mathrm{bc}$ & $5.7 \mathrm{bc}$ \\
Shepody & $6.8 \mathrm{c}$ & $5.9 \mathrm{bc}$ \\
Viking & $5.6 \mathrm{bc}$ & $5.1 \mathrm{~b}$ \\
\hline
\end{tabular}

y Values are $\ln (\mathrm{CFU} / \mathrm{g}$ of stem apices).

${ }^{\mathrm{z}}$ Within year, values with the same letter did not differ significantly according to Fisher's protected least significant difference test $(P \leq 0.05)$. of 'Red La Soda' and 'Viking' were inconsistent between years. In 1996, 'Red La Soda', but not 'Viking', was affected by inoculum density. The reverse was true in 1997.

Aerial biomass. With a decrease in amount of applied water, aerial biomass was significantly reduced in all cultivars in both years ( $P=0.0001$ and $P=0.0001$ in 1996 and 1997 , respectively) (Table 2). Aerial biomass was reduced by 36 and 62\% (1996) and by 33 and $58 \%$ (1997) when amount of applied water was decreased. Inoculum density of $V$. dahliae resulted in a significant $(P=$ $0.026)$ decrease $(11 \%)$ in aerial biomass in 1997 , but had no effect in 1996.

Apical stem assay. $V$. dahliae was recovered from stem apices in all cultivars grown in infested soil, whereas insignificant populations were recovered from noninfested soil. Cultivars differed, however, in population size recovered in $1996(P=0.0001)$ and $1997(P=0.0001)$ (Table 3). The amount of $V$. dahliae recovered from the stem apices was significantly lower in 'Katahdin' in 1996 and in both 'Katahdin' and 'Ranger Russet' in 1997 compared with the other cultivars.

Graded tuber yield. Amount of applied water had a major impact on tuber yield components. There were significant interactions of cultivar $\times$ amount of applied water for size classes $<113 \mathrm{~g}$ and 171 to $340 \mathrm{~g}$ in both 1996 and 1997. Cultivar differences within these interactions, however, varied between years. The overall effect was that yields of smaller tubers $(<170 \mathrm{~g})$ were higher in the driest plots than in wetter plots, and as the amount of applied water increased, yields of tubers greater than $170 \mathrm{~g}$ increased. Main effects of cultivar (Table 4) and amount of applied water (Table 5) were significant for marketable tubers (combined yield components of tubers 113 to $170 \mathrm{~g}, 171$ to $340 \mathrm{~g}$, and >340 g). There were no interactions influencing this response variable. Inoculum density of Verticillium had no effect on marketable yield.

The water $\times$ cultivar interaction for nonmarketable tubers (culls plus $<113 \mathrm{~g})$ was significant in both $1996(P=0.0002)$ and 1997 $(P=0.0165)$ (Fig. 4). With a decrease in amount of applied water, yield of this class did not change for 'Katahdin' and 'Ranger Russet'. Only in 1996 was there a significant main effect of $V$. dahliae $(P=0.0004)$ with a decrease $(29 \%)$ in nonmarketable tubers from the infested plots.

TABLE 4. Main effect of potato cultivar on yield of marketable tubers across irrigation and Verticillium dahliae inoculum treatments in 1996 and 1997

\begin{tabular}{lcc}
\hline & \multicolumn{2}{c}{ Tuber yield $^{\mathrm{y}}$} \\
\cline { 2 - 3 } Cultivar & 1996 & 1997 \\
\hline Katahdin & $13.9 \mathrm{ab}^{\mathrm{z}}$ & $19.6 \mathrm{a}$ \\
Ranger Russet & $11.4 \mathrm{~cd}$ & $17.5 \mathrm{bc}$ \\
Red La Soda & $14.9 \mathrm{a}$ & $18.8 \mathrm{ab}$ \\
Russet Burbank & $11.3 \mathrm{~d}$ & $17.0 \mathrm{~cd}$ \\
Shepody & $11.4 \mathrm{~cd}$ & $17.0 \mathrm{~cd}$ \\
Viking & $12.4 \mathrm{bc}$ & $16.0 \mathrm{~d}$ \\
\hline
\end{tabular}

y Values presented are kilograms per plot.

${ }^{z}$ Within year, values with the same letter did not differ significantly according to Fisher's protected least significant difference test $(P \leq 0.05)$.

TABLE 5. Main effect of amount of applied water on yield of marketable tubers across cultivar and Verticillium dahliae inoculum treatments in 1996 and 1997

\begin{tabular}{lcc}
\hline & \multicolumn{2}{c}{ Tuber yield $^{\mathrm{y}}$} \\
\cline { 2 - 3 } Irrigation treatment $^{\mathrm{x}}$ & 1996 & 1997 \\
\hline Low & $6.3 \mathrm{a}^{\mathrm{z}}$ & $11.4 \mathrm{a}$ \\
Medium & $14.0 \mathrm{~b}$ & $18.6 \mathrm{~b}$ \\
High & $16.8 \mathrm{c}$ & $22.9 \mathrm{c}$ \\
\hline
\end{tabular}

$\bar{x}$ Water was applied by a line source irrigation system. A total of 27,44 , or $61 \mathrm{~cm}$ and 17,31, or $41 \mathrm{~cm}$ of water was applied in 1996 and 1997, respectively. y Values presented are kilograms per plot.

z Within year, values with the same letter did not differ significantly according to Fisher's protected least significant difference test $(P \leq 0.05)$. 


\section{DISCUSSION}

The severity of foliar senescence due to moisture deficit stress paralleled that associated with $V$. dahliae in four of the six potato cultivars. Based on the amount of foliar senescence, tolerance of mild moisture deficit stress corresponded with resistance to Verticillium wilt in 'Katahdin'. 'Ranger Russet' was also resistant to Verticillium wilt, but more sensitive to moisture stress than 'Katahdin'. In contrast, significant increases in foliar senescence developed in response to mild moisture deficit stress and also in response to inoculum of $V$. dahliae in 'Russet Burbank' and 'Shepody'. Populations of $V$. dahliae recovered from the stem apices were small in 'Ranger Russet' and 'Katahdin' and large in 'Shepody' and 'Russet Burbank'.

'Mild moisture deficit stress' is distinguished from 'drought' in that the former is imposed by applying water in amounts that are

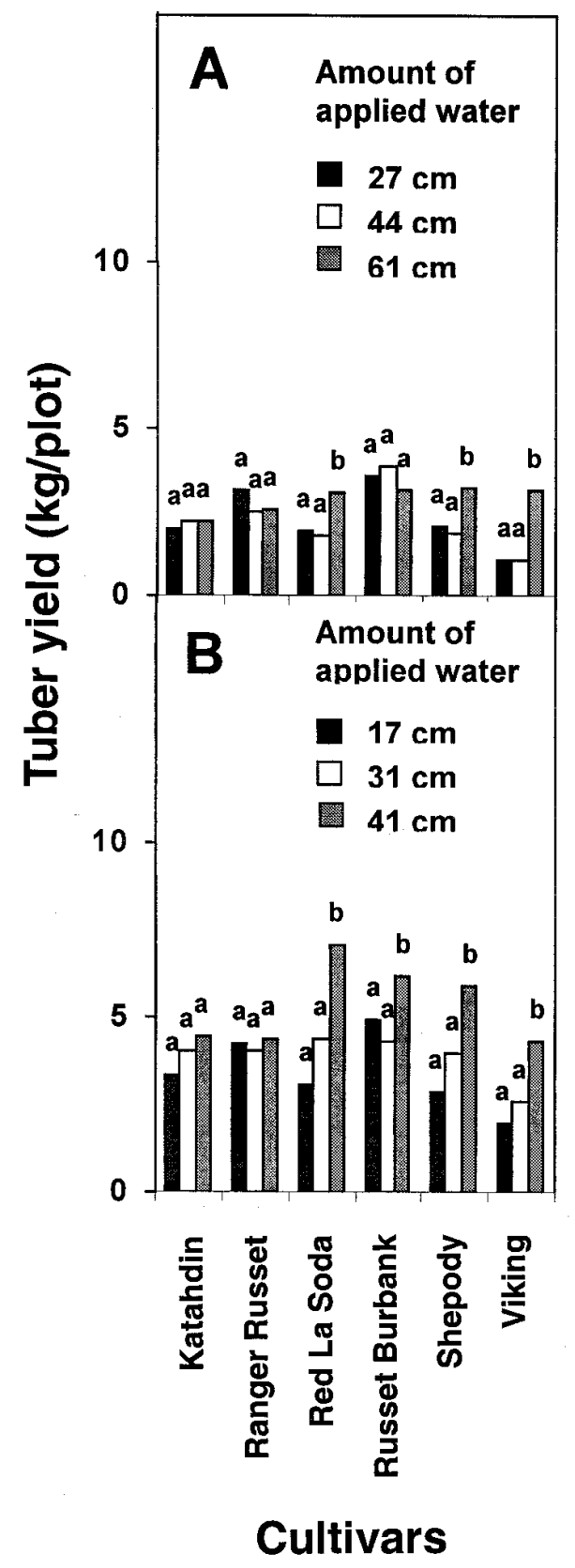

Fig. 4. Amount of applied water $\times$ cultivar interactions on nonmarketable tuber yield of potato in A, 1996 and B, 1997. Within cultivars, bars with the same letter did not differ significantly according to Fisher's protected least significant difference test $(P \leq 0.05)$. Amount of applied water $\times$ cultivar interaction was $P=0.0002$ in 1996 and $P=0.016$ in 1997 . detrimental to plant health and performance but frequent enough so that some soil moisture is maintained throughout the season (26). In contrast, 'drought' is an absence of irrigation or rainfall for a period of time long enough to result in soil water depletion to levels that severely restrict plant growth and health (27), followed by irrigation or natural rainfall. This cycle may be repeated a number of times, with each event termed a 'drought episode.' In our study, irrigation frequency and duration were the same for the three moisture treatments; however, each treatment received a different amount of water, depending upon the distance from the irrigation line. Therefore, consistent, mild moisture deficit stress was created at the greatest distance from the irrigation line. In this treatment (the least amount of applied water), the average percent volumetric soil water at $15 \mathrm{~cm}$ deep, approximately $24-\mathrm{h}$ postirrigation, was 4 and 6\% in 1996 and 1997, respectively. These values are below the $12 \%$ volumetric soil water designated as the permanent wilting point for a loam soil (25). Surface soil can dry beyond the wilting point if irrigation is infrequent enough to replenish water used by the crop and lost to the atmosphere. At the same time, however, soil at depths below the $15 \mathrm{~cm}$ may contain sufficient water for plant growth. Sufficient subsurface moisture for crop growth may explain why growth still occurred in the driest plots.

There was no cultivar $\times$ amount of applied water $\times$ inoculum density interaction for foliar senescence. Had there been such a three-way interaction, some cultivars would have had more severe disease than others when grown in wet soils in the presence of Verticillium. Likewise, some cultivars would have had more severe foliar senescence than others when grown in dry soils in the presence of Verticillium. Mild moisture deficit stress had no direct effect on severity of Verticillium wilt. This is in contrast to earlier studies by Cappaert et al. $(5,6)$ that showed that Verticillium wilt was favored by moist soils. This disparity in results may be attributed to differences in both methodology and environmental conditions. In the studies of Cappaert et al. $(5,6)$, irrigation frequency differed among treatments, whereas in our study, the frequency of irrigation was the same, but different amounts of water were applied. A second consideration is the difference between irrigation treatments. Our wettest treatment was set at $100 \%$ ECU of the plant, rather than a treatment of excessive water that resulted in more disease in the Cappaert et al. studies $(5,6)$. Had we applied water at these higher amounts, disease might have been proportionately higher than what was observed. Wetter soils may promote shallow root growth in the soil profile in which Verticillium inoculum was more concentrated. These factors may explain, in part, why foliar senescence was less severe at the high $(5,6)$ compared with the low amount of applied water in our study.

Environmental conditions at the Madras research site were not very favorable for severe disease expression. The minimum and maximum temperature range for August was 10.6 to $29.8^{\circ} \mathrm{C}$ and 11.7 to $29.7^{\circ} \mathrm{C}$ for 1996 and 1997 , respectively (Table 6), slightly lower than the optimum maximum temperature $\left(21\right.$ to $\left.27^{\circ} \mathrm{C}\right)$ for Verticillium wilt (39). Further, the DDAP reached only 742 and 664 in 1996 and 1997, respectively. Disease severity is not accelerated until after 800 DDAP (6). The length of the growing season in central Oregon is only 90 to 100 days compared with 180 days in the Columbia Basin of Oregon and Washington, where Verti-

TABLE 6. Monthly average of the daily maximum (Max), minimum (Min), and mean temperatures $\left({ }^{\circ} \mathrm{C}\right)$ for Madras, OR, in 1996 and 1997

\begin{tabular}{lrrrrrrrr}
\hline & \multicolumn{3}{c}{1996} & & \multicolumn{3}{c}{1997} \\
\cline { 2 - 3 } \cline { 7 - 8 } Month & Max & Min & Mean & & Max & Min & Mean \\
\hline May & 17.8 & 5.3 & 11.6 & & 22.2 & 7.7 & 15.0 \\
June & 24.2 & 6.6 & 15.4 & & 22.3 & 7.2 & 14.8 \\
July & 31.2 & 11.3 & 21.2 & & 28.5 & 9.8 & 19.1 \\
August & 29.8 & 10.6 & 20.2 & & 29.7 & 11.7 & 20.7 \\
September & 23.7 & 7.2 & 15.4 & & 28.8 & 12.3 & 20.4 \\
Seasonal average & 26.1 & 8.5 & 17.3 & & 26.2 & 9.3 & 17.7 \\
\hline
\end{tabular}


cillium wilt can be a serious problem. The Madras site was chosen because we knew it would be well managed and we anticipated greater disease response. Through experimentation, we learned that a site with a longer growing season might have given anticipated results.

At all moisture levels, $V$. dahliae accelerated foliar senescence. Under season-long, mild moisture deficit stress, however, it was difficult to visually separate the effect of treatment (Verticillium or moisture deficit) on vine death. Therefore, the apical stem assay was used to determine if senescence was due to Verticillium or moisture stress. When Verticillium is the cause of premature senescence, populations of the fungus are high in the stem apices (17). Populations of $V$. dahliae recovered from stem apices of 'Katahdin' were significantly lower than those of all other cultivars except 'Ranger Russet' in 1997. Both 'Shepody' and 'Russet Burbank' had large apical populations of $V$. dahliae in both years. In a study by Davis et al. (18), populations of $V$. dahliae reached $525 \mathrm{CFU} / \mathrm{g}$ of tissue in 'Russet Burbank' before correlations between disease incidence and populations were significant. In our study, populations of $V$. dahliae in 'Russet Burbank' stem apices reached 285 and 299 CFU/g in 1996 and 1997, respectively, which may have been too low to cause a yield reduction. This low infection rate might have been due, in part, to the method of soil infestation. To ensure that contact of the seed piece with enough Verticillium inoculum would occur, inoculum was applied to the furrow at planting with a fertilizer belt. Inoculum was undoubtedly concentrated near the seed piece. However, as the roots grew beyond the furrow, the new root growth may have grown out of contact with the inoculum. In other studies $(19,24,33)$, the soil was naturally infested with $V$. dahliae; therefore, microsclerotia were more evenly distributed throughout the soil profile. By using microplots, Cappaert et al. $(5,6)$ achieved soil infestation by mixing soil with the pathogen in a cement mixer, assuring even distribution of inoculum. This is an effective method on a small scale and not practical on the scale of our experiment.

Aerial biomass at growth stage $\mathrm{V}$ was reduced in both years by similar amounts in all cultivars when amount of applied water was reduced. It has been shown that drought tolerance of a cultivar and total dry matter production are not strongly related (2). A significant decrease in aerial biomass across cultivar and irrigation treatments in 1997 alone was associated with $V$. dahliae infestation. This was likely due to the twofold-higher inoculum density in 1997 compared with 1996.

Analysis of the yield components indicated that these cultivars did not respond differentially to either moisture deficit stress or $V$. dahliae inoculum. A decrease in amount of applied water resulted in an increase in yield of U.S. No. 1s weighing $<170 \mathrm{~g}$ and a decrease in U.S. No. 1s weighing $>170 \mathrm{~g}$. This was probably due to insufficient water during the tuber bulking phase (12). Although interactions of cultivar $\times$ amount of applied water were significant in some size classes in both years, the interactions were inconsistent from year to year. In 1997, V. dahliae was associated with a decrease in U.S. No. 1s weighing $>340$ g. This reduction in yield of large tubers has been previously reported in the presence of $V$. dahliae alone as well as the presence of both $V$. dahliae and the root lesion nematode Pratylenchus penetrans (3). In that study, higher yields of small-sized tubers occurred as well, suggesting that infected plants set more tubers than do healthy plants, but most of these remained small and diverted phytosynthates from the larger tubers. In our study, there were no significant interactions that affected marketable tuber yield. As was the case with foliar senescence, temperatures in Madras were not high enough to allow the Verticillium to impact yield. Rowe et al. (38) reported significant yield reductions due to Verticillium wilt only when the average July-to-August temperature was $24^{\circ} \mathrm{C}$ and little effect on tuber yield when the average July-to-August temperature was $20^{\circ} \mathrm{C}$. Therefore, temperatures were not warm enough to allow $V$. dahliae to cause yield reductions in our study.
In general, potato plants are sensitive to moisture deficits due primarily to their relatively shallow root system. Physiological responses of potato to water deficits may include reduced rate of photosynthesis, reduced canopy expansion, premature senescence (23), decreased host water potential (28), reduced yield, reduced tuber dry matter accumulation, and diminished external quality of tubers $(29,43)$. With reduced plant canopy expansion, soil temperature increases and evapo-transpiration rates may increase.

The physiological aspects of tolerance to moisture deficit stress in potato have been investigated (8). Cultivars that are reported to be drought tolerant may have one or more features such as greater leaf water retention; more epicuticular wax; greater root depth and extension; and greater stomatal number, size, and resistance. The sum of the factors unique to a given cultivar, however, is likely the determinant of cultivar differences in reaction to water stress. For example, Epstein and Grant (21) determined leaf diffusion resistance under conditions of water stress for 'Russet Burbank' and 'Katahdin'. Stomatal diffusion resistance of 'Russet Burbank' was two to three times greater than that of 'Katahdin', suggesting that 'Russet Burbank' was better able to maintain its water levels. The difference in relative water content of the two cultivars, however, was small, suggesting that stomatal diffusion resistance may not be the best indicator of drought tolerance. Necas (31) showed that there are varietal differences in osmotic values of the cell sap at decreasing leaf water potentials. Mechanisms that contribute to cultivar responses to moisture stress may occur at the root level. Davies and Zhang (13) showed that plants in unwatered soil exhibited low conductance when their shoot water potentials were high, suggesting that plants sense the availability of water in the soil. Chemicals such as abscisic acid conveyed from roots to shoots in response to small changes in turgor, volume, or pressure on membranes of only a few roots may regulate stomatal behavior, affecting leaf gas exchange in some plants (13). If the response of potato to available soil water is initiated at the root, as it is to Verticillium, the responses to both stresses may be similar. If a potato cultivar has mechanisms at the root to tolerate mild moisture deficit stress, then some of these same mechanisms may be responsible for resisting infection to $V$. dahliae.

We have established a tentative link between tolerance to moisture deficit stress and resistance to Verticillium wilt in potato. Based on the amount of foliar senescence and population size of $V$. dahliae in the stem apices, 'Katahdin' was classified as both tolerant to moisture deficit stress and resistant to Verticillium wilt. Based on RAUSPC values, 'Ranger Russet' was less tolerant to moisture deficit stress than was 'Katahdin', but it was more tolerant than the other four cultivars in 1996 and was resistant to Verticillium wilt in both years. In contrast, sensitivity to moisture deficit stress corresponded to susceptibility to Verticillium wilt in 'Russet Burbank' and 'Shepody'. 'Viking' and 'Red La Soda' were sensitive to moisture deficit stress and susceptible to Verticillium wilt in terms of apical stem populations, and although foliar senescence for these two cultivars was not significantly increased both years, 'Viking' is reportedly susceptible to Verticillium wilt. These results suggest that the relationship of moisture deficit stress and resistance to Verticillium wilt has the potential to be included in germ plasm screening and justifies more extensive research of this hypothesis. Traditional screening for resistance to Verticillium wilt involves growing potential germ plasm in infested soil (11). By developing the use of moisture deficit stress as the prescreening technique, one could select the best candidates for advance screenings for resistance to Verticillium wilt under greenhouse or field conditions.

\section{ACKNOWLEDGMENTS}

Technical paper 11369 of the Oregon Agricultural Experiment Station. The United States Environmental Protection Agency provided a fellowship for M. Arbogast under the National Network for Environmental 
Management Studies fellowship. We thank C. Pereira for assistance in statistical analysis and data interpretation.

\section{LITERATURE CITED}

1. Baskerville, G. L., and Emin, P. 1969. Rapid estimation of heat accumulation from maximum and minimum temperatures. Ecology 50:514-517.

2. Bodlander, K. B. A. 1986. Effects of drought on water use, photosynthesis and transpiration of potatoes. 1. Drought resistance and water use. Pages 36-43 in: Proc. Potato Research Tomorrow: Drought Tolerance, Virus Resistance and Analytic Breeding Methods. Pudoc Scientific Publishers, Wageningen, the Netherlands.

3. Botseas, D. D., and Rowe, R. C. 1994. Development of potato early dying in response to infection by two pathotypes of Verticillium dahliae and co-infection by Pratylenchus penetrans. Phytopathology 84:275-282.

4. Butterfield, E. J., and DeVay, J. E. 1977. Reassessment of soil assays for Verticillium dahliae. Phytopathology 67:1073-1078.

5. Cappaert, M. R., Powelson, M. L., Christensen, N. W., and Crowe, F. J. 1992. Influence of irrigation on severity of potato early dying and tuber yield. Phytopathology 82:1448-1453.

6. Cappaert, M. R., Powelson, M. L., Christensen, N. W., Stevenson, W. R., and Rouse, D. I. 1994. Assessment of irrigation as a method of managing potato early dying. Phytopathology 84:792-800.

7. Caroselli, N. E. 1957. Verticillium wilt of maples. R.I. Univ. Agric. Exp. Stn. Bull. 335:1-84.

8. Coleman, W. K. 1986. Water relations of the potato (Solanum tuberosum L.) cultivars Raritan and Shepody. Am. Potato J. 63:263-275.

9. Corsini, D. L., Davis, J. R., and Pavek, J. J. 1985. Stability of resistance of potato to strains of Verticillium dahliae from different vegetative compatibility groups. Plant Dis. 69:980-982.

10. Corsini, D. L., and Pavek, J. J. 1996. Agronomic performance of potato germplasm selected for high resistance to Verticillium wilt. Am. Potato J. 73:249-260.

11. Corsini, D. L., Pavek, J. J., and Davis, J. R. 1988. Verticillium wilt resistance in noncultivated tuber-bearing Solanum species. Plant Dis. 72: 148-151.

12. Curwen, D. 1993. Water management. Pages 67-75 in: Potato Health Management. R. C. Rowe, ed. The American Phytopathological Society, St. Paul, MN.

13. Davies, W. J., and Zhang, J. 1991. Root signals and the regulation of growth and development of plants in drying soil. Annu. Rev. Plant Mol. Biol. 42:55-76.

14. Davis, J. R. 1985. Approaches to control of potato early dying caused by Verticillium dahliae. Am. Potato J. 62:177-185.

15. Davis, J. R., and Everson, D. O. 1986. Relation of Verticillium dahliae in soil and potato tissue, irrigation method, and N-fertility to Verticillium wilt of potato. Phytopathology 76:730-736.

16. Davis, J. R., Huisman, O. C., Westermann, D. T., Hafez, S. L., Everson, D. O., Sorensen, L. H., and Schneider, A. T. 1996. Effects of green manures on Verticillium wilt of potato. Phytopathology 86:444-453.

17. Davis, J. R., Pavek, J. J., and Corsini, D. L. 1983. A sensitive method for quantifying Verticillium dahliae colonization in plant tissue and evaluating resistance among potato genotypes. Phytopathology 73: 1009-1014.

18. Davis, J. R., Pavek, J. J., Corsini, D. L., Sorensen, L. H., Schneider, A. T., Everson, D. O., Westermann, D. T., and Huisman, O. C. 1994. Influence of continuous cropping of several potato clones on the epidemiology of Verticillium wilt of potato. Phytopathology 84:207-214.

19. Davis, J. R., and Sorensen, L. H. 1986. Influence of soil solarization at moderate temperatures on potato genotypes with differing resistance to Verticillium dahliae. Phytopathology 76:1021-1026.
20. El-Zik, K. M. 1985. Integrated control of Verticillium wilt of cotton. Plant Dis. 69:1025-1032.

21. Epstein, E., and Grant, W. J. 1973. Water stress relations of the potato plant under field conditions. Agron. J. 65:400-404.

22. Francl, L. J., Madden, L. V., Rowe, R. C., and Riedel, R. M. 1990. Correlation of growing season environmental variables and the effect of early dying on potato yield. Phytopathology 80:425-432.

23. Jeffries, R. A., and Mackerron, D. K. L. 1993. Responses of potato genotypes to drought. II. Leaf area index, growth and yield. Ann. Appl. Biol. 122:105-112.

24. Kotcon, J. B., Rouse, D. I., and Mitchell, J. E. 1984. Dynamics of root growth in potato fields affected by the early dying syndrome. Phytopathology 74:462-467.

25. Kramer, P. J. 1983. Soil and water. Pages 57-83 in: Water Relations of Plants. Academic Press, New York.

26. Kramer, P. J. 1983. Water deficits and plant growth. Pages 342-389 in: Water Relations of Plants. Academic Press, New York.

27. Kramer, P. J. 1983. Drought tolerance and water use efficiency. Pages 390-415 in: Water Relations of Plants. Academic Press, New York.

28. Krikum, J., and Orion, D. 1979. Verticillium wilt of potato: Importance and control. Phytoparasitica 7:107-116.

29. Levy, D. 1985. The response of potatoes to a single transient heat or drought stress imposed at different stages of tuber growth. Potato Res. 28:415-424.

30. Mosley, A. R., and Chase, R. W. 1993. Selecting cultivars and obtaining healthy seed lots. Pages 20-21 in: Potato Health Management. R. C. Rowe, ed. The American Phytopathological Society, St. Paul, MN.

31. Necas, J. 1974. Physiological approach to the analysis of some complex characters of potatoes. Potato Res. 17:3-23.

32. Nelson, R. 1950. Verticillium wilt of peppermint. Mich. State Univ. Agric. Exp. Stn. Tech. Bull. 221:1-259.

33. Nnodu, E. C., and Harrison, M. D. 1979. The relationship between Verticillium albo-atrum inoculum density and potato yield. Am. Potato J. 56: $11-25$.

34. Powelson, M. L. 1979. Verticillium wilt of potatoes in irrigated sands: The Oregon experience. Oreg. Agric. Exp. Stn. Tech. Pap. 5106.

35. Powelson, M. L., and Rowe, R. C. 1993. Biology and management of early dying of potatoes. Annu. Rev. Phytopathol. 31:111-126.

36. Rowe, R. C., Davis, J. R., Powelson, M. L., and Rouse, D. I. 1987. Potato early dying: Casual agents and management strategies. Plant Dis. 71:482-489.

37. Rowe, R. C., and Riedel, R. M. 1976. Association of Pratylenchus penetrans with the "early dying" disease complex of potatoes. Fungic. Nematic. Tests 31:218.

38. Rowe, R. C., Riedel, R. M., and Martin, M. J. 1985. Synergistic interactions between Verticillium dahliae and Pratylenchus penetrans in potato early dying disease. Phytopathology 75:412-418.

39. Schnathorst, W. C. 1981. Life cycle and epidemiology of Verticillium. Pages 81-111 in: Fungal Wilt Diseases of Plants. M. E. Mace, A. A. Bell, and C. H. Beckman, eds. Academic Press, New York.

40. Schnieder, H. 1948. Susceptibility of guyule to Verticillium wilt and influence of soil temperature and moisture on development of infection. J. Agric. Res. 76:129-143.

41. Shaner, G., and Finney, R. E. 1977. The effect of nitrogen fertilization on the expression of slow-mildewing resistance in Knox wheat. Phytopathology 67:1051-1056.

42. Sorensen, L. H., Schneider, A. T., and Davis, J. R. 1991. Influence of sodium polygalacturonate sources and improved recovery of Verticillium spp. from soil. (Abstr.) Phytopathology 81:1347.

43. van Loon, C. D. 1981. The effect of water stress on potato growth, development, and yield. Am. Potato J. 58:51-56. 